\title{
Use of a reflection journal in a third year engineering project course
}

\author{
A.L. Steele \\ Dept. of Electronics, Carleton University \\ asteele@,doe.carleton.ca
}

\begin{abstract}
As part of a new third year project course for the Electrical Engineering program, a reflection journal was introduced as part of the work to be undertaken by students. The aim of the one term course is to provide a project experience that will provide design experience in teams, will draw together material from the previous years of academic study as well as further prepare students for their capstone project. The reflection journal has been introduced to provide a regular opportunity for the student to consciously reflect on their progress, challenges encountered, as well as a way to develop their writing skills. This is an attempt to encourage students to look at the process of learning in a project environment and to develop some degree of metacognition1. By undertaking this type of reflection Cowan [1] suggests that this assists students from looking at solving a particular challenge to generalizing the problem solving process, fitting with the objectives of a project course. The entries for the journal are weekly and are assessed each week by an instructor and contributed to $15 \%$ of the final mark. Because this form of assessment would be new to most of the students instructions were provided including a rubric. These instructions as well as the instructor's experiences and opinion of the success of the journal will be presented.
\end{abstract}

Keywords: Engineering project, reflection journal, learning journal, metacognition, design project

\section{INTRODUCTION}

Reflection journals in education, or learning journals, are chronicled entries of the learner that examine the process of learning and the acquiring of knowledge in a course or across courses. Such journals are often used in the education of professionals, such as teacher or nurses [2]. These types of journals have also been used in educating student of engineering [3-5]. Beyond the training of newcomers to a discipline they can been used in the professional development process or continuous professional development. Moon points out that "A general characteristic of professional development journals is their willingness to address past, present and the anticipation of future practice - not just present action" [2].

Reflection is a key stage in the Kolb learning cycle theory [1]. In this theory in a cyclic flow reflection follows active experimentation and concrete experience, and is followed by abstract conceptualization [1]. This repeating cycle models the process of the accumulation of knowledge and its practice, a process model that could be applied to the design process in engineering.

In the Winter term 2013 a new mandatory third year course for students in the Electrical Engineering program was run for the first time. This course was ELEC3907 Engineering Project. This is a single term course based around a group project and, in part, is preparation for the final year capstone project (for which ELEC3907 is now a prerequisite). Since this is a single term course the intention was to attempt to increase the learning of the process of project work, such as working in a team, managing time, project design, development and testing, through the use of a reflection journal. Since a project involves conceptualization of a solution to a problem, experimentation and experience then if one follows Kolb's theory the student undertaking the project should be involved in reflection, before future conceptualization. In an attempt to encourage this reflection it was decided to introduce the reflection journal as a part of the assessment.

The ways students may learn from a reflection journal are outline by Moon [2], in particular in chapter 3 or [2]. Quoting Moon directly [2] she lists the following:

- "slows the pace of learning

- can increase the sense of ownership of learning

- acknowledges the role of emotion in learning

- gives learners an experience of dealing with illstructured material of learning

- encourages metacognition

- enhances learning through the process of writing"

Possible topics of the writing in a project reflection journal could be quite rich, ranging from formulation of a solution to the main goal, approaches to breaking down the design task into elements, allocation task and inter group communication, design of circuits and testing, analysis of results, understanding and refining 
specifications. Moon [2] also outlines the depth that can be encountered in reflection journals. In increasing depth of reflection these are listed as:

- Descriptive writing

- Descriptive account with some reflection

- Reflective writing (level 1) motives and reason exploration 'standing back'

- Reflective writing (level 2) metacognitive. Selfquestioning. Personal frame of reference.

Consideration was given as to whether the reflection should be part of the assessment. An argument could be made as to whether one could judge another individuals reflection on a specific problem. Alternatively, not to have some element of assessment could lead to the consideration that the reflection journal was unimportant. After research on the assessment of learning or reflection journals, with the help of online resources [6,7] it was ultimately decided to assess and mark the learning journals and to make them $15 \%$ of the final grade.

The findings reported here are the observations made by one of the course instructors (there were two in the Winter 2013 course offering) and the insight that was obtained in reading and assessing each student's weekly reflection. For consistency the same instructor marked all the reflections.

\section{THE REFLECTION JOURNAL WITHIN THE THIRD YEAR PROJECT COURSE}

\subsection{Course Structure}

The course was a new course designed to give electrical engineering students experience of group project work and design. It is a single term (Winter) 0.5 credit course that is required for all electrical engineering students and is part of the third year of their degree program. It is not to replace the capstone project but is to provide some experience that could provide good preparation for the capstone project. In modifying the electrical engineering program to include the new third year project a complementary studies elective was removed.

The course had a scheduled 7 hours of laboratory time and a one hour lecture class. The lecture class was used in a variety of ways, including lectures on microcontroller programing, guest lecturers talking about design. As well, the lecture was regularly used for students presentations on their project, including design outlines, problem discussions so groups could discuss with other groups and final presentations.

Laboratory time was focused on the project work. Include group discussion and planning, component selection, construction, testing and trouble shooting. Projects were selected by the students, as was the group allocation. Microcontroller boards and sensors had been purchased prior to the class starting and an indication on what was initially available did give some level of direction on the project selection. Once projects were underway items were ordered almost weekly provided they were within a sensible budget. The main microcontroller board selected was a Jeenode [8], an open source hardware board that was compatible with the Arduino.

Assessment was based on proposal, oral presentation, project reports, technical assessment of the project and a reflection journal.

\subsection{Reflection Journal}

Each week every student was required to write a reflection on some aspect of the past week's project activities. This was to be submitted sometime within the next week. There was no set time for the week's entry to be submitted, nor on what the reflection should be written in. This was to allow flexibility and hopefully allow the reflection to be easier to make. Consideration had been given to asking for submissions to be submitted only electronically, but it was decided to try the flexibility of paper or electronics. In the first year of running it the majority used paper and a small handful submitted electronically. The number of books and papers did mean that it was easier to collect and move the books in two boxes, one indicated 'for marking' to other 'marked'.

To help the students understand the process of the reflection journal and the reasons for including this activity and part of the assessment there was a briefing given as well as a written outline and rubric, see Table 1 . The students were informed the journal was private and would not be shared with other students. It was noted that there may be some sharing with other professors who were interested in the reflection journal, such as the program's communications course instructors. This privacy was introduced to encourage the reflection on topics like team members, group dynamics and differences of opinion. This was intended to move the reflection beyond just the technical work and to make the reflection more holistic. It should be noted that a statement was included in the learning journal outline document regarding disclosure to the relevant services if there was a perceived threat of harm to the self or others. The online resources [6,7] provided the guidelines for these approaches to making a framework around the learning journals.

To supplement the rubric and to illustrate to the type of entries that could be possible examples were given of a fictional poor, satisfactory and good entries. Another example was given that was not graded and the student was encouraged to assess the grade themselves.

To encourage the reflection it was decided to not be too prescriptive in the content nor the amount written. It was indicated that if the reflection was less than half a side it was probably too brief. 
Table 1: The reflection journal rubric.

\begin{tabular}{|c|c|c|c|}
\hline & Excellent (3) & $\begin{array}{l}\text { Satisfactory } \\
\text { (2) }\end{array}$ & Poor (1) \\
\hline $\begin{array}{l}\text { Reflection: } \\
\text { (Ability to } \\
\text { consider } \\
\text { experiences } \\
\text { and critically } \\
\text { assess work } \\
\text { issues and } \\
\text { outcomes) }\end{array}$ & $\begin{array}{l}\text { Shows } \\
\text { strong } \\
\text { critical } \\
\text { thinking and } \\
\text { creative } \\
\text { solutions. } \\
\text { Examination } \\
\text { of issues } \\
\text { from } \\
\text { different } \\
\text { perspectives. }\end{array}$ & $\begin{array}{l}\text { Evidence of } \\
\text { appropriate } \\
\text { analysis of } \\
\text { the work } \\
\text { undertaken. } \\
\text { However, } \\
\text { lack of } \\
\text { extended } \\
\text { analysis and } \\
\text { examination } \\
\text { from } \\
\text { different } \\
\text { perspectives. }\end{array}$ & $\begin{array}{l}\text { Limited or } \\
\text { no } \\
\text { reflection. } \\
\text { Straight } \\
\text { forward } \\
\text { description } \\
\text { provided. }\end{array}$ \\
\hline $\begin{array}{l}\text { Presenta- } \\
\text { tion: } \\
\text { (Organiza- } \\
\text { tion of ideas, } \\
\text { opinions and } \\
\text { perspectives. } \\
\text { Quality of } \\
\text { grammar, } \\
\text { punctuation } \\
\text { and spelling) }\end{array}$ & $\begin{array}{l}\text { Well } \\
\text { organized } \\
\text { writing with } \\
\text { coherent } \\
\text { flow of } \\
\text { ideas. } \\
\text { Written with } \\
\text { no, or very } \\
\text { few, spelling } \\
\text { mistakes and } \\
\text { good } \\
\text { sentence } \\
\text { structure. }\end{array}$ & $\begin{array}{l}\text { Ideas and } \\
\text { arguments } \\
\text { there but } \\
\text { could be } \\
\text { arranged to } \\
\text { make a } \\
\text { better case } \\
\text { or flow. } \\
\text { Some poor } \\
\text { grammar } \\
\text { and/or } \\
\text { spelling } \\
\text { mistakes. }\end{array}$ & $\begin{array}{l}\text { Little } \\
\text { original } \\
\text { thinking. } \\
\text { Badly } \\
\text { organized. } \\
\text { Many } \\
\text { spelling } \\
\text { mistakes and } \\
\text { grammatical } \\
\text { mistakes. } \\
\text { Content } \\
\text { confusing. } \\
\text { Illegible in } \\
\text { parts if } \\
\text { handwritten. }\end{array}$ \\
\hline
\end{tabular}

\section{EXPERIENCES AND OBSERVATIONS}

The qualitative experiences and observations from the instructor will be given here.

\subsection{Students Response to the Reflection Journal}

When the activity of learning journals was intially revealed some student were heard commenting that they had to write about how they "feel" about their project. However, the task of getting a group together and selecting a project was a focusing activity and it lent itself well to reflection for the first entry.

Submissions were regular for most students and with 48 students this led to a significant amount of weekly reading. Entries came in notebooks, pads, folios and handwritten or printed sheets of paper.

Some early entries were poorly laid out, for example as set of bullet points in one case, and there was some writing was of poor quality. With regular feedback the writing quickly improved until there was a consistent level of satisfactory writing. It was noticed that some students for whom English was a second language their writing improved over the term to a significantly higher standard than at the start of the term.
The reflections did vary in depth, as could be expected from previous published research and as mentioned in section 1. Many entries were descriptions of work done over the week and students had to be encouraged to be more reflective. This was done by written feedback with the marks. For a number who were encouraged to deepen their reflection this subsequently occurred but only to a marginal degree. A few did consistently reflect and this would be about the project, sometimes about working with others, rarely about how other courses helped them, often about the project course lectures and how they found them useful, occasionally about design and towards the end of the term about time management. One student was a strong reflector and did produce about 4 sides of reflection weekly, which would cover many areas, including in one instance a discussion on the design elements of cars they had driven. In this specific case there was no enough evidence that this individual had reached the 4th depth level mentioned above, despite being who I would categorize as one of the most reflective of the students from their journal. Overall very few did go into deep reflection in their journals and most kept to the first level of depth mentioned in section 1 .

There was variation in style in reflections. Often the reflection jumped straight into the detail and it was difficult sometimes to know which project was being talked about as many were using the same microcontroller board. Sometimes there was more description of what the group had achieved rather than what the individual had achieved. It was possible to see individual 'voices'and styles coming through the reflections.

From a course instructor perspective it was good to see how the projects were progressing. Occasionally some project advice or suggestion was given in the feedback on the journal, but usually comments were restricted to the journaling process.

The journaling was encouraged and continued right up to the conclusion of project and the final summary reflections were often insightful as to how the students considered the project experience, as well as a chance taken by some to deepen their reflection. For example, students talked about what they had learned from the project, and the themes of working with others, time management and preparation for the capstone did come up.

Only three students did not submit any reflection journals. Most students continued throughout the course to reflect regularly. Less than 10 were intermittent submitters, by not submitting every week. This indicates the task was not overly onerous for a student.

\subsection{Instructor Observation on the Reflection Journal}

The weekly marking of all the reflection journals was found to be a considerable task. The collection of paper and books proved to impractical for easy movement for marking at home at a weekend. A mundane but important 
consideration if timely feedback is to be given. Electronic journals would provide more flexibility for marking at opportune times away from the office or laboratory.

There was a noticeable reticence of some to expand beyond the descriptive reflection, despite comments to encourage deeper reflection. This may need to address in future years by further examples or in-class discussion after a few weeks of journaling.

Perhaps the most noticeable improvement was the actual writing. This did seem to improve to the point that the majority of students we obtaining full marks in the area of presentation, based on the rubric. This had not been anticipated on being a major outcome although there was an expectation that the experience of writing weekly would have some impact.

Assessing the reflection was challenging at times and did require repeated and careful reading to critically assess the reflection level. Sometimes it was an obvious reflection when group interactions were raised, sometimes critically, or if alternatives approaches were being weighed. It was most challenging when brief entries were made and the content was mostly descriptive and there were hints of reflection on the technical process.

\section{CONCLUSION and FUTURE WORK}

The reflection journal was found to be readily accepted by the majority of students. The majority regularly submitted a journal throughout the term. This may have been due to the marks associated with the journals. The depth of the reflection was usually at the level of descriptive and keeping to what had been worked on in the week. Stepping beyond this descriptive reflection was found to be uncommon. When it was done there were a few regular themes of teamwork, time management and reflecting on lectures, especially guest lectures.

The logistics of marking were challenging especially due to the number of students. If the class size grows additional resources may be needed to mark the weekly submissions and in which case care will need to be put into consistency of grading.

One noticeable affect of the regular submissions and feedback was the improvement in writing and general presentation. There was a variety to the submissions, whether hand written accounts in notebooks, printed pages produced on a word processor or an emailed file.

In future it is intended to continue the reflection journals. However, for ease of collection and marking it is intended to move towards an electronic only submission, most likely through the learning management system.

To encourage the deepening of reflections the use of more examples or further in-class discussions need to be considered. Thought has also been given to one or more of the instructors having a course reflection journal and making that open to the students.
Ultimately, whether the reflection journal has helped students develop deeper insights in project undertaking, management and design is difficult to assess. There is published evidence that indicates reflection or learning journals do help students [1,2, and 5]. The regular feedback to the instructor was valuable insight to how the students were progressing and generally finding the course. Even if that was the only benefit it was probably a useful exercise, but it is suspected that students did gain when actively reflecting on their projects.

\section{Acknowledgements}

I would like to thank the third year ELEC3907 engineering project students who took the course in Winter 2013 and my colleague and fellow course instructor Prof. Q. J. Zhang.

\section{References}

[1] John Cowan, On Becoming an Innovative University Teacher, Reflection in Action. Open University Press, 2006, 228 pp. \{ISBN 0-335-21992-6\}

[2] Jennifer A. Moon, Learning Journals. A handbook for reflective practice and professional development. Routledge, 2006, (2nd. Ed.), 200 pp. \{ISBN 0-415-40376\}

[3] Stuart Palmer, "Evaluation of an On-Line Reflective Journal in Engineering Education", Computer applications in engineering education, vol. 12, no. 4, pp. 209-214, 2004

[4] Susan Hawkins, Mary B. Hawkins and Karl-Erik Bystrom, "Incidental Writing in the Engineering Classroom", J. of Engineering Education, 85, pp. 27-33, 1996

[5] V. A. Burrows, B. McNeil, N. F. Hubele and L. Bellamy, "Statistical Evidence for Enhanced Learning of Content through Reflective Journal Writing", J. of Engineering Education, 90, pp. 661-667, 2001

[6] The Centre for the Enhancement of Teaching and Learning, The University of Hong Kong, "Assessment Resources: Reflective Journal”. Accessed 3rd May 2013 from http://ar.cetl.hku.hk/pdf/ReflectiveJournal.pdf

[7] Jennifer A. Moon, “Assessment: Learning Journals and Logs", University College Dublin Teaching and Learning Resources, January 2010. Accessed 3rd May 2013 from http://ar.cetl.hku.hk/pdf/ucdtla0035.pdf

[8] The Jeenode description in the Jeelabs online store Accessed 3rd May 2013 from http://jeelabs.com/products/jeenode 